\title{
DAMAGE TO THE HISTORIC TOWN OF STAUFEN (GERMANY) CAUSED BY GEOTHERMAL DRILLINGS THROUGH ANHYDRITE-BEARING FORMATIONS
}

\author{
ŠKODA V ZGODOVINSKEM MESTU STAUFEN (NEMČIJA) \\ POVZROČENA Z GEOTERMALNIM VRTANJEM SKOZI \\ ANHIDRITNE FORMACIJE
}

Ingo SASS ${ }^{1} \&$ Ulrich BURBAUM ${ }^{2}$

\begin{abstract}
UDC 504.6:550.822(430)

Ingo Sass \& Ulrich Burbaum: Damage to the historic town of Staufen (Germany) caused by geothermal drillings through anhydrite-bearing formations

Shallow geothermal systems for the heating and cooling of buildings will play an important role in the future renewable energy supply. Especially in dense settlements the geothermal energy utilization for facility heating and cooling is very promising. Therefore, it is important to analyse the damage to Staufen im Breisgau (Germany). In September of 2007, seven geothermal borehole heat exchanger (BHE) drillings were performed in a small square directly adjacent to the $16^{\text {th }}$ century town hall in the centre of the town. These led to enormous structural damage to buildings as a function of four different geological parameters: artesian groundwater, two interacting karst formations, strong tectonization, and a swellable anhydrite formation. Some weeks after termination of the well construction, uplift started, and recently (March 2010) reached a magnitude of approximately $26 \mathrm{~cm}$. Actually, some 250 buildings (March 2010) are involved; showing cracks, tilting, and other effects of the differential swelling movements beneath the foundations. Surface uplifts with rate up to $10 \mathrm{~mm} / \mathrm{month}$ have been determined using high-resolution spaceborne radar data and radarinterferometric techniques. These amplitudes correlate with data from benchmarks of terrestrial geodetic surveyng. Besides the uplift due to the swelling processes, future problems could arise from the fact that the gypsum formed from the swelled anhydrite is soluble in water. Thus, sinkholes and other karst related phenomena may occur.

Keywords: Anhydrite swelling, borehole heat exchangers, borehole heat exchanger drillings, damage to buildings, gypsum karst.
\end{abstract}

Povzetek UDK 504.6:550.822(430)

Ingo Sass \& Ulrich Burbaum: Škoda v zgodovinskem mestu Staufen (Nemčija) povzročena z geotermalnim vrtanjem skozi anhidritne formacije

Plitvi geotermalni sistemi za ogrevanje in ohlajanje zgradb bodo v prihodnje igrali pomembno vlogo pri oskrbi z obnovljivo energijo. Zlasti v gosto poseljenih naseljih je koriščenje geotermalne energije mnogo obetajoče za ogrevanje in hlajenje. Zato je pomembno analizirati škodo povzročeno v Staufnu, Breisgau (Nemčija). Septembra 2007 je bilo v centru mesta, na manjšem trgu v neposredni bližini mestne hiše iz 16. stoletja, izvedeno vrtanje sedmih geotermalnih vrtin za toplotno izmenjavo (VTI). Vrtanje je povzročilo ogromno škode na stavbah, saj je vplivalo na štiri različne geološke parametre: na arteško podtalnico, medsebojno vplivanje kraških formacij, močno tektonizacijo in na nabrekanje anhidritnih formacij. Nekaj tednov po zaključku izdelave vrtin se je pričelo dvigovanje in je marca 2010 doseglo premike do približno $26 \mathrm{~cm}$. Dejansko je bilo do marca 2010 poškodovanih okoli 250 stavb, kjer so opazne razpoke, nagibi in druge posledice različnih premikov pri nabrekanju pod temelji. Površinski premiki s stopnjo do $10 \mathrm{~mm} / \mathrm{mesec}$ so bili določeni z interferometričnimi tehnikami in obdelavo podatkov visokoločljivega satelitskega radarja. Te razsežnosti so $\mathrm{v}$ korelaciji $\mathrm{z}$ oznakami relativnih višin izmerjenimi s terestičnimi geodetskimi meritvami. Poleg dvigovanja, ki ga je povzročilo nabrekanje, lahko v prihodnosti nastanejo dodatni problemi $\mathrm{z}$ raztapljanjem iz anhidrita nastale sadre. Tako lahko pride do nastanka udora in drugih pojavov, ki so povezani s korozijo.

Ključne besede: nabrekanje anhidrita, vrtin za toplotno izmenjavo, škoda na poslopjih, sadreni kras.

\footnotetext{
${ }^{1}$ Technische Universität Darmstadt, Institut für Angewandte Geowissenschaften, Schnittspahnstraße 9, 64287 Darmstadt, e-mail: sass@geo.tu-darmstadt.de

${ }^{2}$ CDM Consult GmbH, Motorstraße 5, 70499 Stuttgart
}

Received/Prejeto: 26.2.2010 


\section{DAMAGE SYMPTOMS}

Staufen im Breisgau (Staufen) is located in the southwestern Germany on the western flank of the Upper Rhine Valley graben (Fig. 1). The drilling of seven shallow borehole heat exchangers (BHE) at the City of Staufen triggered a series of events in completely different domains that have caused a very problematic situation. The complicated process is not completely investigated today. Since the installation of the BHE in September 2007, the subsoil in the inner city shows an uplift of up to approximately $10 \mathrm{~mm} / \mathrm{month}$ (LGRB 2009). The current cumulative value (as of March 2010) is approximately $26 \mathrm{~cm}$. The geothermal wells were drilled up to $140 \mathrm{~m}$ depth, and were intended to supply the town hall with geothermal energy for heating and cooling purposes.

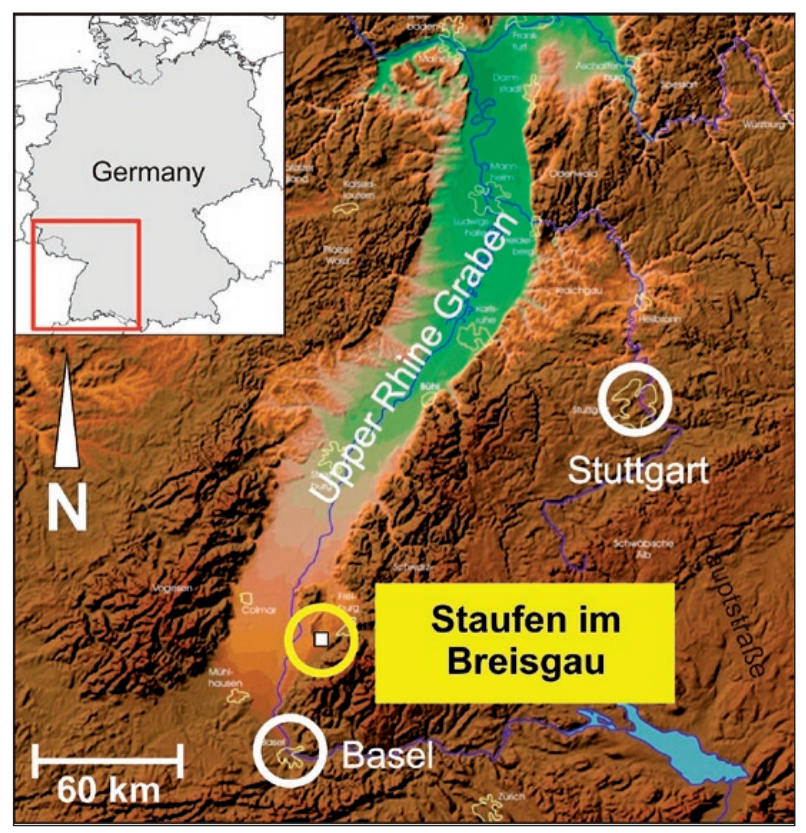

Fig. 1: Staufen im Breisgau.

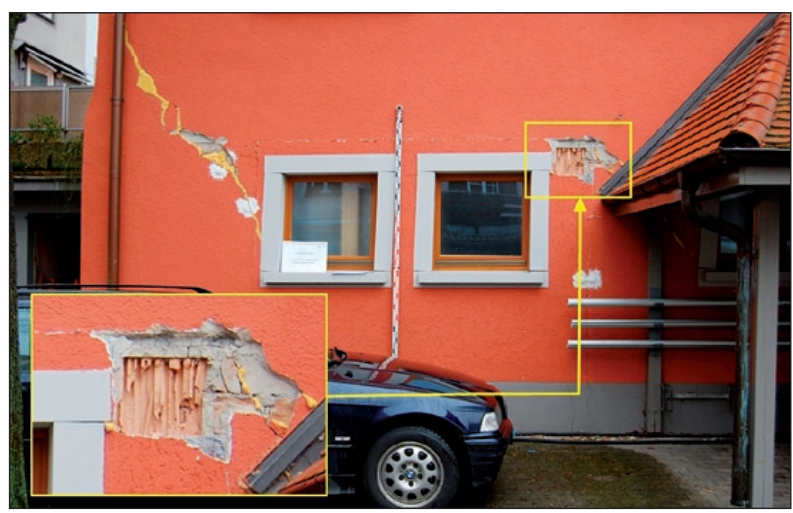

Fig. 2: Uplift cracks in building Kirchstraße, inner courtyard, distance to the well field approx. $20 \mathrm{~m}$ to the east. Destruction of the supporting masonry, March 2009 (Photo: U. Burbaum).
The differential uplift affects buildings as well as infrastructure by inducing stresses which exceed the tension and shear strengths of the structural components, producing tension and shear cracks (Figs. 2 and 3). In addition, the deformations also cause tilting, which in turn puts compressive stress on bearing elements. The uniaxial compressive strength of construction components is locally exceeded, and they fail. Damages to the local infrastructure (Fig. 4) are severe. For example, gas and water utilities require expansion bends (Fig. 5) to prevent future desasters. The damage patterns are dependent upon the tectonic setting, the lithologic conditions, hydrogeological heterogeneity, and the BHE drilling geometry as well as varying BHE construction quality.

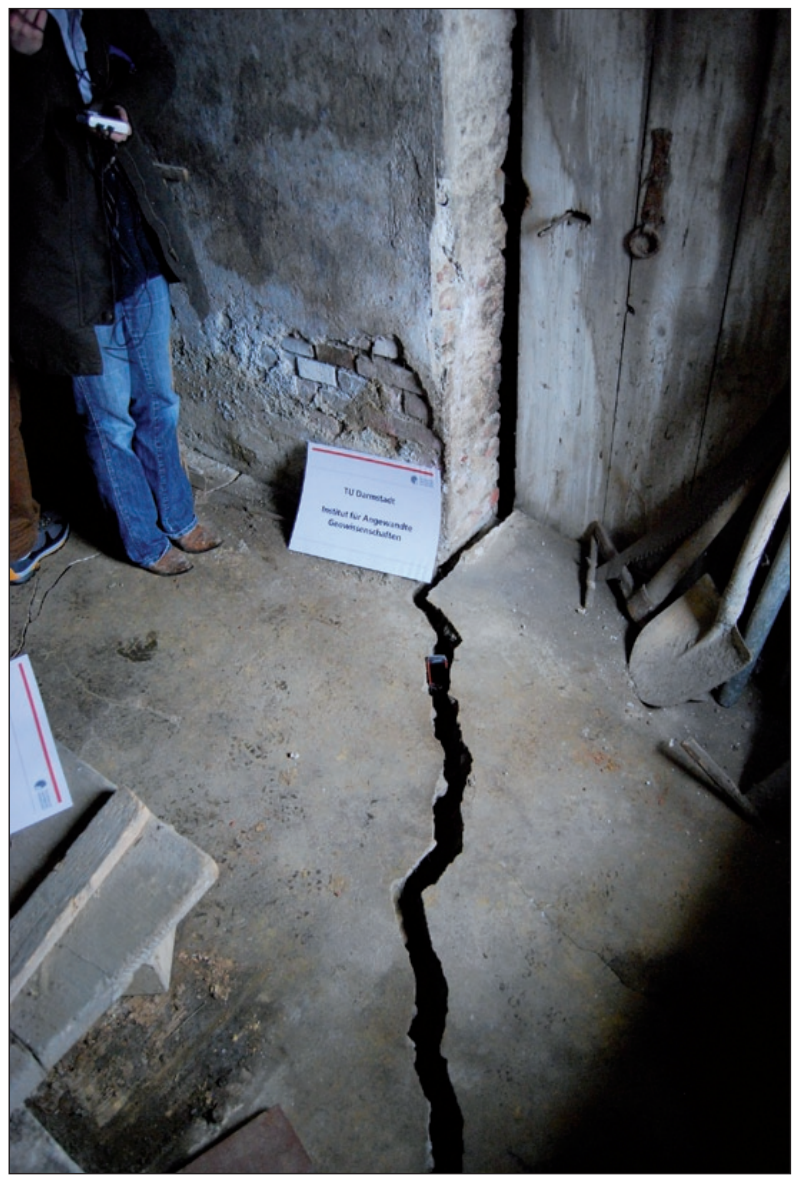

Fig. 3: Tension crack in a baseplate, building Jägergasse, distance to the well field approx. $70 \mathrm{~m}$ to the northeast, March 2009 (Photo: U. Burbaum).

Apertures of cracks typically range up to some centimeters, with some more than $10 \mathrm{~cm}$. To date (March 2010) approximately 250 houses are seriously affected, and the number is still increasing (although this num- 


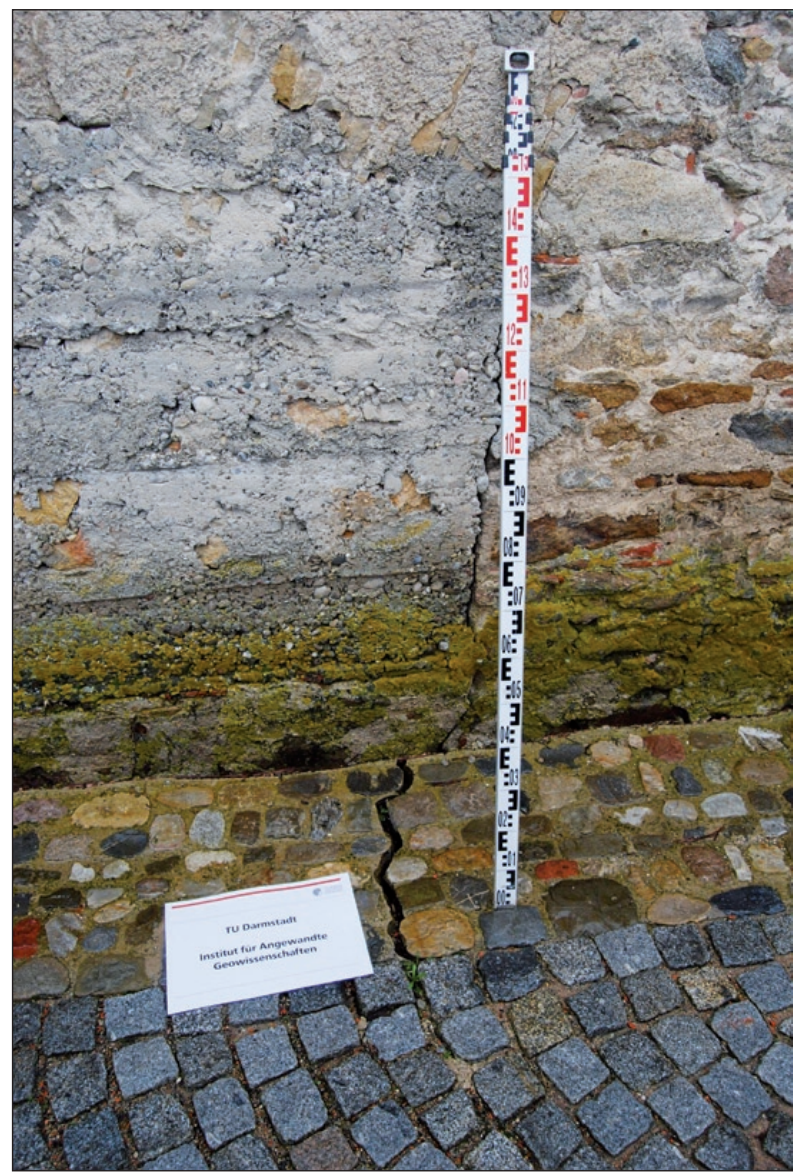

Fig. 4: Crack in the street "Jägergasse", distance to the wellfield approx. $80 \mathrm{~m}$ to the NE, March 2009 (Photo: U. Burbaum).

ber may include cracks formed in objects that could not verifiably be linked to the uplifting process). Therefore, it appears that the area of damage is growing, and that the uplift in vertical as well as in radial extension around the well field persists and damages rises.

The financial damage, and the best point of time for reconstruction of buildings and infrastructure, are not

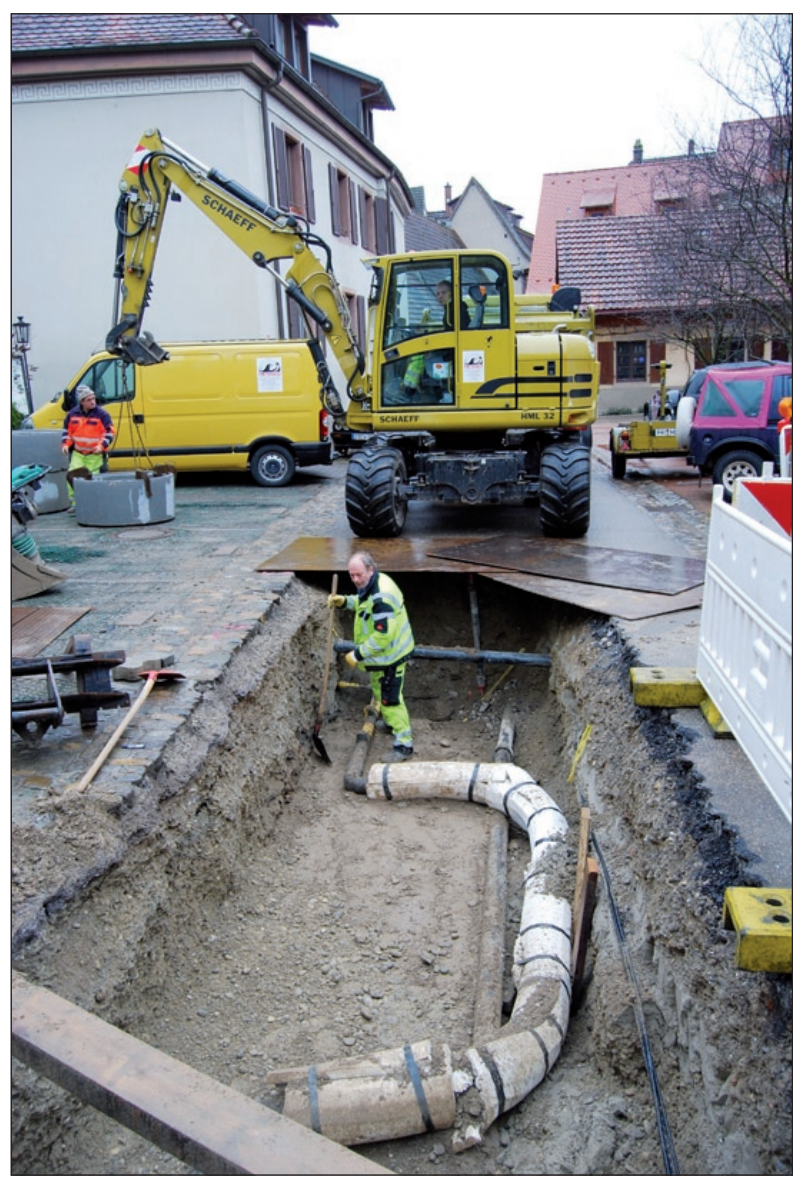

Fig. 5: Installation of an expansion bend in a PE-HD gas pipe, Meiergasse, distance to the well field approx. $80 \mathrm{~m}$ in northnortheast direction, March 2009 (Photo: U. Burbaum).

determinable since the swelling persists and is quantitatively not predictable to date. Thus, an economic basis for the claim settlement does not exist. A method to quantify the restoration and compensation costs must be developed in the near future.

\section{GEOLOGY AND ANHYDRITE SWELLING}

The location of Staufen on the western flank of the Upper Rhine Valley graben (Fig. 6) is affected by complex and partially unexplored tectonic conditions (Landesvermessungsamt Baden-Württemberg 1996). Fig. 7 shows a NW-SE geologic cross-section in the area of the inner city (after Schreiner 1991, as cited in a report by the Landesanstalt für Umweltschutz Baden-Württemberg 2005). Small scale features of shearing, compressive and extensive tectonic movements are typical, and produce multi-phase fracture systems (Geyer \& Gwinner 1991).

Thus, the quantitative determination of the groundwater movement and its flow paths is difficult. However, it is most likely that the fracture system can provide various hydraulic connections. Drilling risks should therefore be categorized as high since drill holes could collapse, or other problems may occur. 


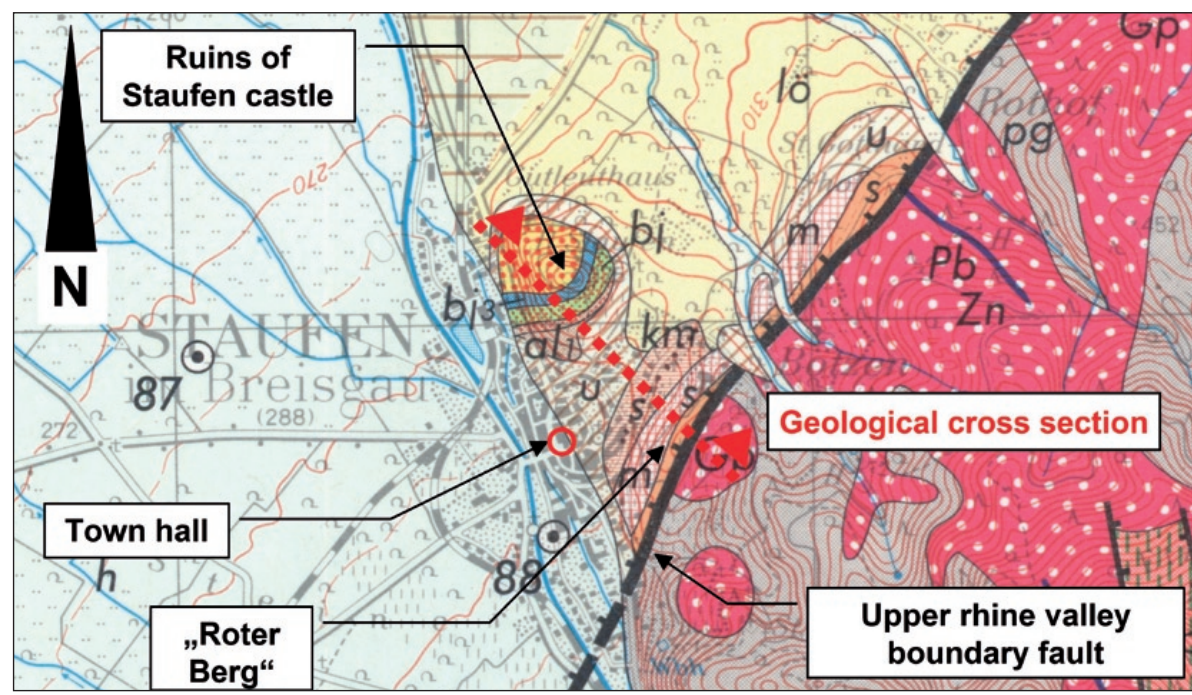

Fig. 6: Modified detail image of the geological map of Freiburg, M 1:50.000. (Landesvermessungsamt BadenWürttemberg 1996).

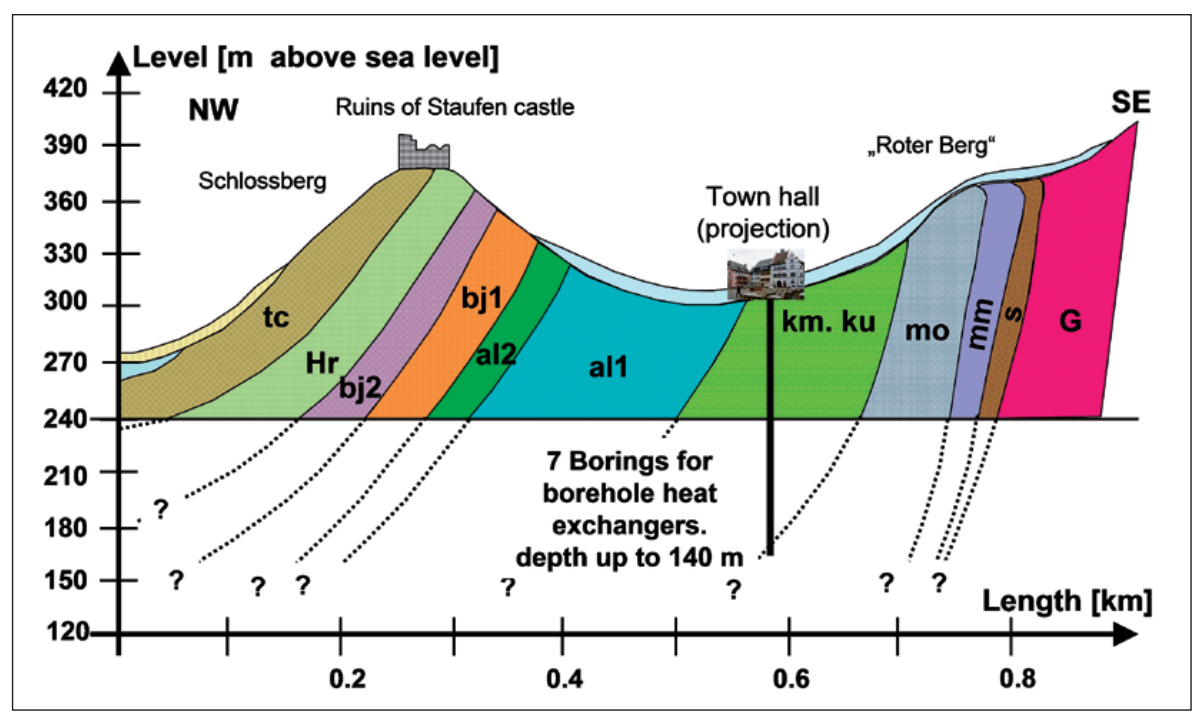

Fig. 7: Geological cross section NW-SE (modified after Schreiner, A. 1991, cited in: Landesanstalt für Umweltschutz Baden-Württemberg 2005).

$t c=$ Tertiary conglomerate, $\mathrm{Hr}=$ Hauptrogenstein, bj2 = Bajocian 2, bj1 = Bajocian 1, al2 = Aalenian 2, al1 = Aalenian 1: Opalinus clay, $\mathrm{km}=$ Middle Keuper, $k u=$ Lower Keuper, $m o=$ Upper Muschelkalk, $m m=$ Middle Muschelkalk, $s=$ Buntsandstein, $G=$ Granite.

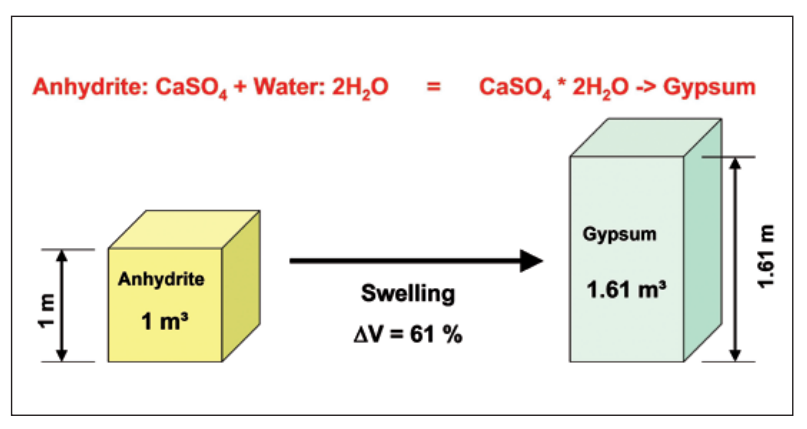

Fig. 8: Swelling process of anhydrite into gypsum.
Complicated groundwater conditions, and local occurrence of artesian groundwaters, are typical at the Rhine Valley flanks. For this reason, the guidelines for the utilization of shallow geothermal energy (LGRB 2005) of Baden-Wuerttemberg assigns geothermal well drillings into the highest case; group D. This group permits geothermal drillings only after individual examinations, and only under certain technical and regulatory conditions.

The general stratification in the vicinity of the town hall (Figs. 6 and 7) can be taken from the geological map (Landesvermessungsamt Baden-Württemberg 1996; Landesvermessungsamt BadenWürttemberg 1999), which proved to be quite appropriate. Basically, thin-bedded strata of Jurassic age cover some meters of Schilfsandstein (Stuttgart Formation) and Gipskeuper (Grabfeld Formation). The Gipskeuper reaches a thickness of about 100 to $150 \mathrm{~m}$ (Geyer \& Gwinner 1991) throughout the southwest of Baden-Wurttemberg.

In Staufen, wells proved a thickness of about $100 \mathrm{~m}$. The geothermal probes presumably reached their final depths in the Lettenkeuper (Erfurt Formation). The underlying Muschelkalk has not been drilled yet (according to known well logs, Gemeinde Staufen 2007). One research drilling later reached the Muschelkalk in Summer 2009. However, the Lettenkeuper has only some meters thickness and due to the structural fracturing, the hydraulic head of the Muschelkalk is probably connected to the drill site. Due to the petrographic patterns and the strong tectonics, the Lettenkeuper has to be regarded as an aquiferaquitard intercalation. The hydrogeological map (LGRB 1977) shows limestone, and dolomite, respectively, in the vicinity of Staufen. This could be Muschelkalk (Landes- 


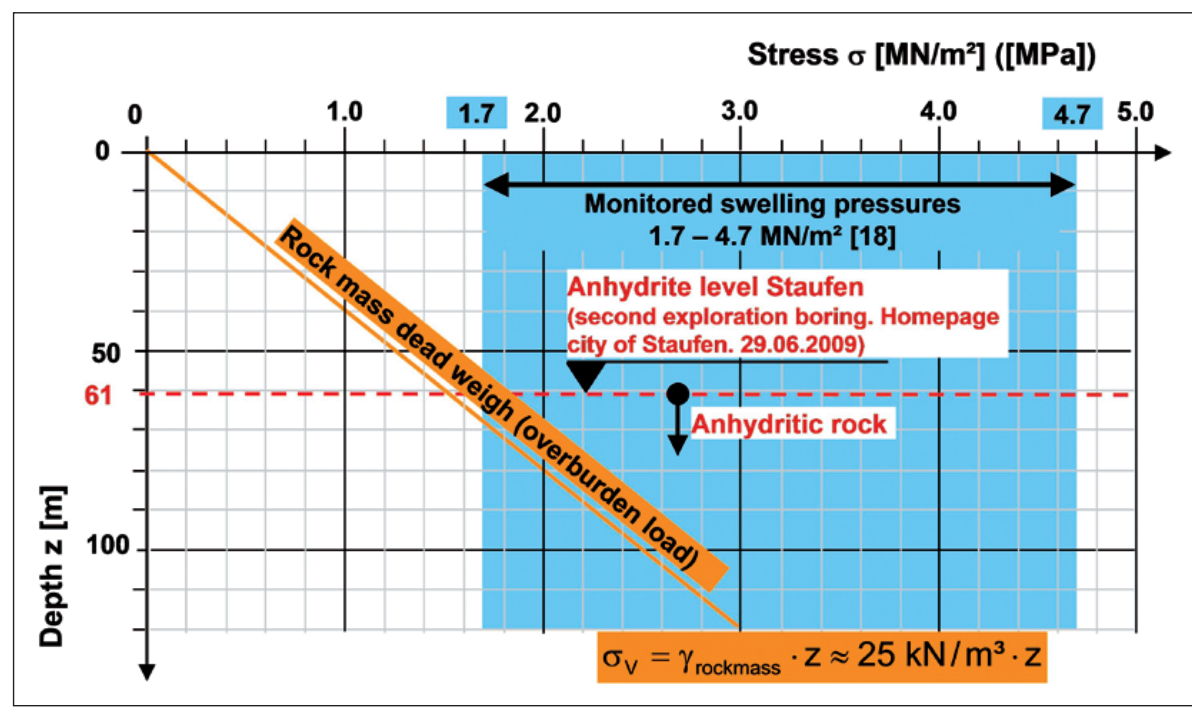

Fig. 9: Swelling pressure (modified from Steiner 1989, 1993, 2007).

vermessungsamt Baden-Württemberg 1996; LGRB 1977; Wagenplast 2005). The aquifers in the Muschelkalk have, due to their location and their catchment areas on the higher ground in the outlying hills, the potential to be artesian in the inner city districts of Staufen (Fig. 7).

When anhydrite and water interact, anhydrite recrystallizes as gypsum. This process involves swell- ing in the formation, with an increase of volume up to $60 \%$ (Fig. 8). Swelling processes in anhydrite have been described often (Chiesi et al. 2010; Steiner 1989, 1993, 2007). If swelling is prevented due to confining conditions, immense swelling pressures may occur. In some tunnel projects in anhydrite rock, swelling pressures from 1.7 up to $4.7 \mathrm{MPa}$ were monitored (Steiner 1989, 1993, 2007). Swelling could be avoided only if sufficient overburden rock mass is present. The relationship between necessary overburden rock mass and possible swelling pressure is shown in Fig. 9. The dead weight of rock mass related to its depth is compared to the swelling pressure monitored by Steiner (Steiner 1989, 1993, 2007). The anhydrite rock in Staufen is located at about $60 \mathrm{~m}$ depth (see below). Thus, the overburden rock mass is insufficient to prevent swelling.

\section{BOREHOLE HEAT EXCHANGER SYSTEMS}

Worldwide, several systems for borehole heat exchangers (BHE) are established. The capacity of a borehole heat exchanger is essentially determined by the thermal properties of the surrounding ground and the backfilling in the

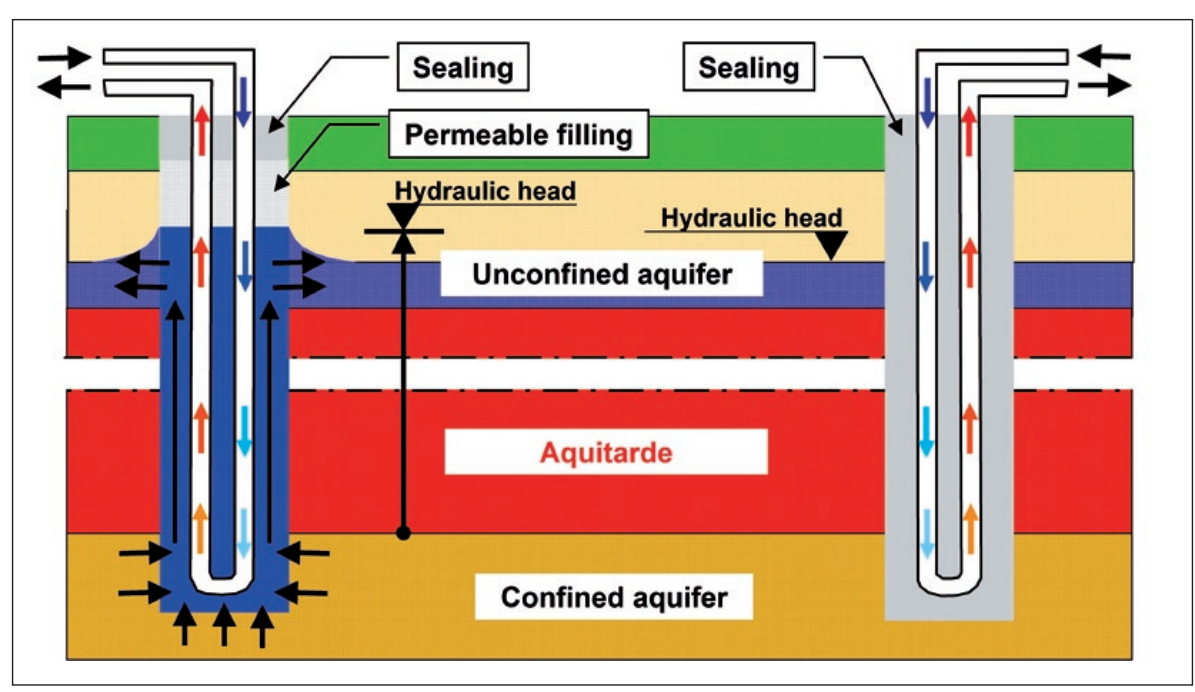

annular space between exchanger pipes and borehole lining. The heat transport from the surrounding ground to the pipes is dominated by groundwater. For a good heat transport, the borehole backfill should be as permeable as possible (unsealed $\mathrm{BHE}$ systems, Fig. 10, left side). If groundwater is present, it is thermally most efficient to use no backfill. However, regulations in Germany require a complete grouting of the annular space.

A great advantage of sealed systems (Fig. 9 right side) is the protection of

Fig. 10: Filling of borings for borehole heat exchangers.

Left: Unsealed BHE, Right: Sealed BHE 
groundwater resources. Using ungrouted BHE systems, heat exchanger fluids (if they contain antifreeze agents like monoehtyleneglycol) may contaminate groundwater in case of a leakage from the pipes. Furthermore, layered aquifers are kept from communicating with each other. Additionally, surface contaminants may infiltrate downward into groundwater resources in unsealed BHE systems.

Therefore, in some countries authorities require a sealing by use of an impermeable backfill. National rules in this particular matter vary widely. However, from a hydrogeological perspective, the sealing of $\mathrm{BHE}$ is indis- pensible and the thermal capacity of borehole heat exchangers is then somewhat decreased. But the reduced performance of such a BHE is an acceptable trade-off.

For this reason, in Germany, the joining of two aquifers is forbidden. Each borehole of a heat exchanger has to be sealed by a cementbased backfill, which can be thermally enhanced to reduce the negative impact on the BHE performance. The backfill grout must be durable for long-term use according to groundwater quality, and it must be grouted from the borehole bottom to the top to provide a proper seal.

\section{BOREHOLE HEAT EXCHANGER INSTALLATION IN STAUFEN}

The drilling, cementing and casing operations on all seven double-U-tube geothermal probes (S1 to S7 in chronological order) were performed between 03.09.2007 and 21.09.2007 (Figs. 10, 11 and 12, Tab. 1) (Report 2007b). Distances between wells are at least 4.5 to $10 \mathrm{~m}$. It is noticeable that the drill logs of S2 report a final depth of $105 \mathrm{~m}$, while the planned and the authorized depth was 140 m (Gemeinde Staufen 2007; Landratsamt BreisgauHochschwarzwald 2007, Report 2007a). Presumably, the borehole collapsed below a depth of $105 \mathrm{~m}$. S1 also collapsed from 135 to $140 \mathrm{~m}$ before installation of the heat exchanger pipes. Collapsed borehole sections cannot be grouted successfully.

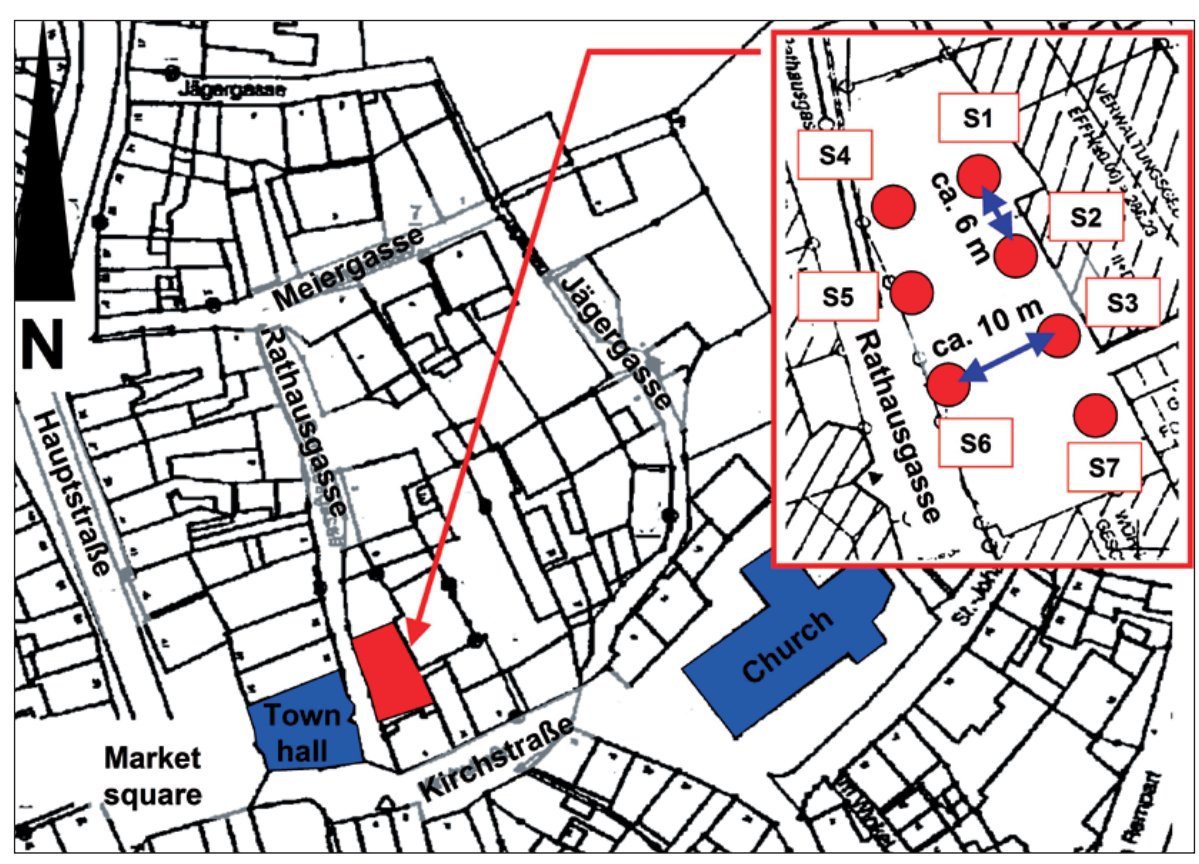

Tab. 1: Data of borings (Report 2007b).

\begin{tabular}{lccc}
\hline Boring & $\begin{array}{c}\text { Length } \\
\text { (drilled) } \\
{[\mathrm{m}]}\end{array}$ & $\begin{array}{c}\text { Length } \\
\text { (completed) } \\
{[\mathrm{m}]}\end{array}$ & \multicolumn{1}{c}{ Diameter } \\
\hline S1 & 140 & 135 & $\begin{array}{l}0-14 \mathrm{~m}: 161 \mathrm{~mm} \\
14-135 \mathrm{m:}: 135 \mathrm{~mm}\end{array}$ \\
\hline S2 & 140 & 105 & $\begin{array}{l}0-14 \mathrm{~m}: 161 \mathrm{~mm} \\
14-105 \mathrm{~m}: 135 \mathrm{~mm}\end{array}$ \\
\hline S3 - S7 & 140 & 140 & $\begin{array}{l}0-14 \mathrm{~m}: 161 \mathrm{~mm} \\
14-140 \mathrm{~m}: 135 \mathrm{~mm}\end{array}$ \\
\hline
\end{tabular}

Wells were drilled with a roller bit, and pressurized air was used as the drilling fluid. The surface casings extended to a depth of up to $14 \mathrm{~m}$ (Report 2007b).

Well S1 reportedly penetrated artesian groundwater at a depth of $32 \mathrm{~m}$. The piezometric level at the wellhead was at about $0.5 \mathrm{~m}$ above ground surface ( $\mathrm{Re}$ port 2007b). All other wells did not encounter artesian conditions (according to residents and the administration of Staufen). It can be concluded that the hydraulic potential of the Muschelkalk karst aquifer was connected

Fig. 11: Site sketch of well locations with interspaces at the city of Staufen town centre. 
to the borehole S1 via fractures penetrating the Lettenkeuper layers. However, drilling contractor well logs show artesian conditions in all wells. Information on artesian control during drilling operations are missing in the well logs.

A water-suspended mixture of powdered clay and cement was used as backfilling grout. The amount of

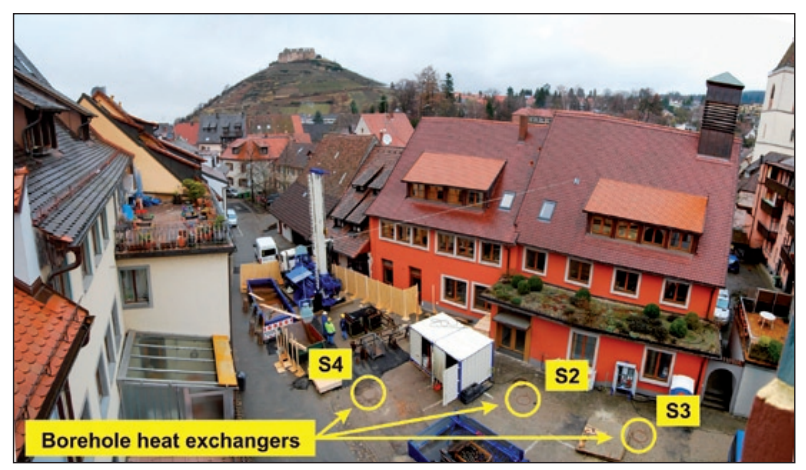

Fig. 12: Borehole heat exchanger field at Rathausgasse with drill rig for the first exploration boring for determining the cause of damage (March 2009). Photo taken from the tower of the town hall by U. Burbaum.

injected grout materials are shown in Tab. 2 (Report 2007b). Noticeable is well S2 which had a grout take much larger than predicted.

Tab. 2: Volume of sealing material in boreholes S1-S7 (Report 2007b).

\begin{tabular}{lccc}
\hline Boring & $\begin{array}{c}\text { Gross volume } \\
\text { (target) } \\
{\left[\mathrm{m}^{3}\right]}\end{array}$ & $\begin{array}{c}\text { Injected amount } \\
\text { according to logs } \\
\text { (actual) }\left[\mathrm{m}^{3}\right]\end{array}$ & $\begin{array}{c}\text { Difference } \\
{\left[\mathrm{m}^{3}\right]}\end{array}$ \\
\hline S1 & 2.01 & 2.23 & 0.22 \\
\hline S2 & 1.59 & 2.00 & -0.41 \\
\hline S3 - S7 & 2.09 & 2.00 & -0.09 \\
\hline
\end{tabular}

Well S1 was drilled to its planned depth, but the borehole could not be cemented and backfilled for the last $5 \mathrm{~m}$ due to cave-ins. It is uncertain whether the filled excavations are all sealed-off. Due to the fact that the drilling operations were performed with only a short surficial casing, groundwater could ascend through the fracture system into the anhydrite- and possibly corrensite-bearing zones of the Gipskeuper, which is located be-

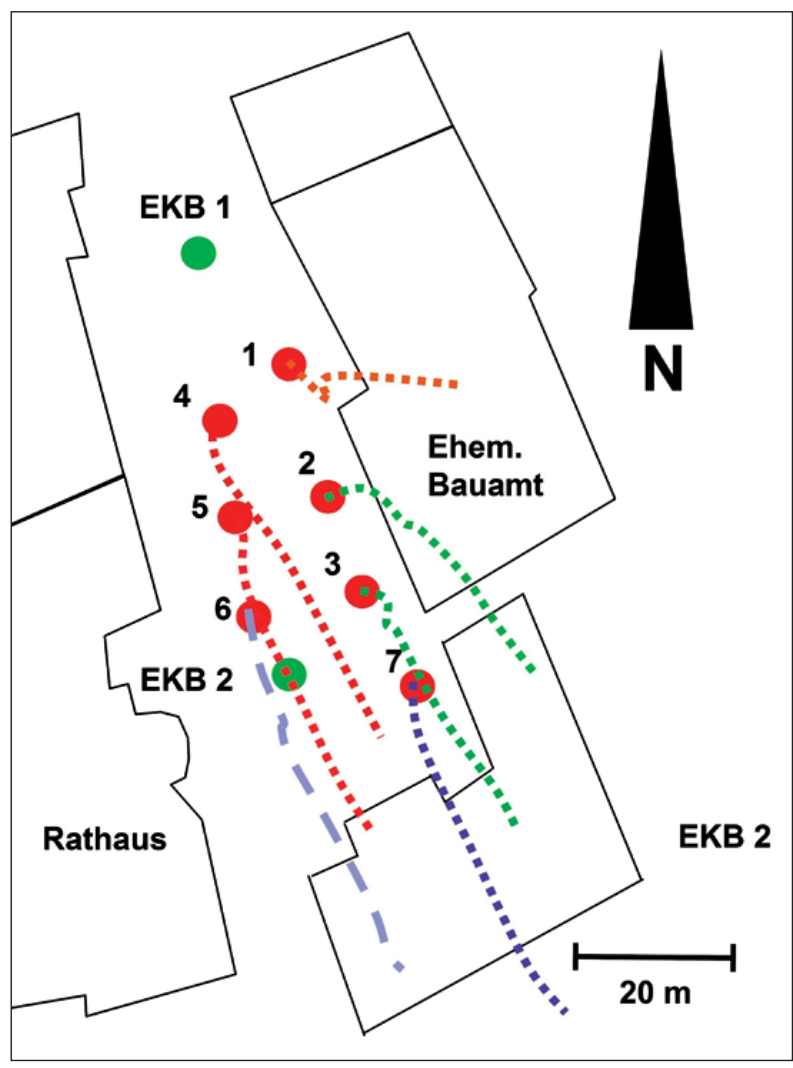

Fig. 13: Deviation of drillings.

low the gypsum level. Based on later surveys, it is likely that a fault was penetrated. Later observations (see below) suggest the swelling process was possibly triggered with the first well drilling operation.

The second well (S2) presumably penetrated the same fault or another related fault at about $105 \mathrm{~m}$ depth, as suggested by cave-ins prior to the installation of the geothermal probe at 140 to $105 \mathrm{~m}$. These flow paths were probably not sealed off completely during the drilling operation.

An investigation of the inclination of the drillings shows a great horizontal deviation of all drillings up to some $20 \mathrm{~m}$ (LGRB 2010). This is shown in Fig. 13. The main deviation occurs in a depth of approx. 60 to $70 \mathrm{~m}$. The depth correlates with the lower end of the temporary drilling casings.

\section{UPLIFT IN THE URBAN AREA OF STAUFEN}

In November 2007, only 6 to 8 weeks after finishing the installation of the BHE, the first cracks were noticed in buildings. Cracks were quite small at first, and were not linked to the drilling operations. From 12/2007 to $01 / 2008$ cracks were marked with gypsum markers (Fig. 14). 
Soon so many buildings were affected that geodetic leveling measurements were performed (Schad 2008), and revealed an extensive uplift of the town centre of Staufen.

The distribution of the uplift has been monitored since the 22.07.2008 by high-resolution, satellite-aided radar data (Petrat \& Al-Enezi 2006). The procedure is based on radar interferometry, which has the advantage of an extensive monitoring of ground movement under

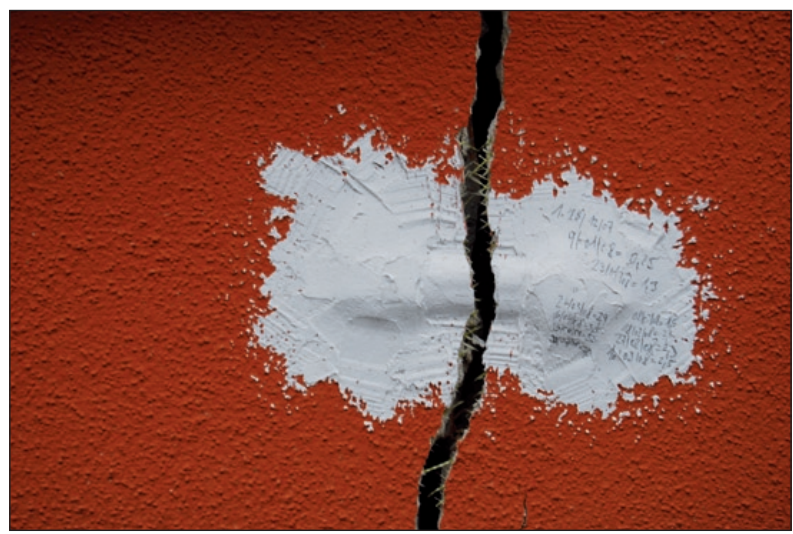

Fig. 14: Gypsum markers on a crack, building Rathausgasse 3, with logs of the fracture spacing since December 2007 (Photo from March 2009 by I. Sass \& U. Burbaum).

ideal conditions. Radar interferometry is used in mining and oil and gas production (Petrat \& Al-Enezi 2006). Small scale and complex ground and building movements can be monitored and measured quite well using the high (better than $1 \mathrm{~m}$ ) resolution satellite data. Highresolution satellite images are provided through the radar satellite TerraSAR-X, which has been commercially active since 2008. TerraSAR-X has a comparatively short circulation time of 11 days (by comparison to conventional radar satellite systems), which allows a reliable temporally-variable monitoring of the ground movements. Data shown in Fig. 15 are withdrawn from Petrat (Petrat \& Al-Enezi 2006; Sass et al. 2009). TerraSAR-X operates at a wavelength of $3.1 \mathrm{~cm}$. The movement of the buildings was monitored in the so called StripMap mode, totaling nine data sets. Phase differences can be determined by comparing individual data sets, and are shown in interferograms. Differences are generally determined by analyzing the topography and ground movement that occurred between two succeeding data sets (satellite passes). After a revision of the topographic phase, each interferogram shows movement-related phase fractions, which can be converted into ground movement by assuming a movement direction. The data commonly contains atmospheric phases, which can be reduced by adequate stacking or by integrating multiple succeeding data sets. Data analysis suggests a considerable ground
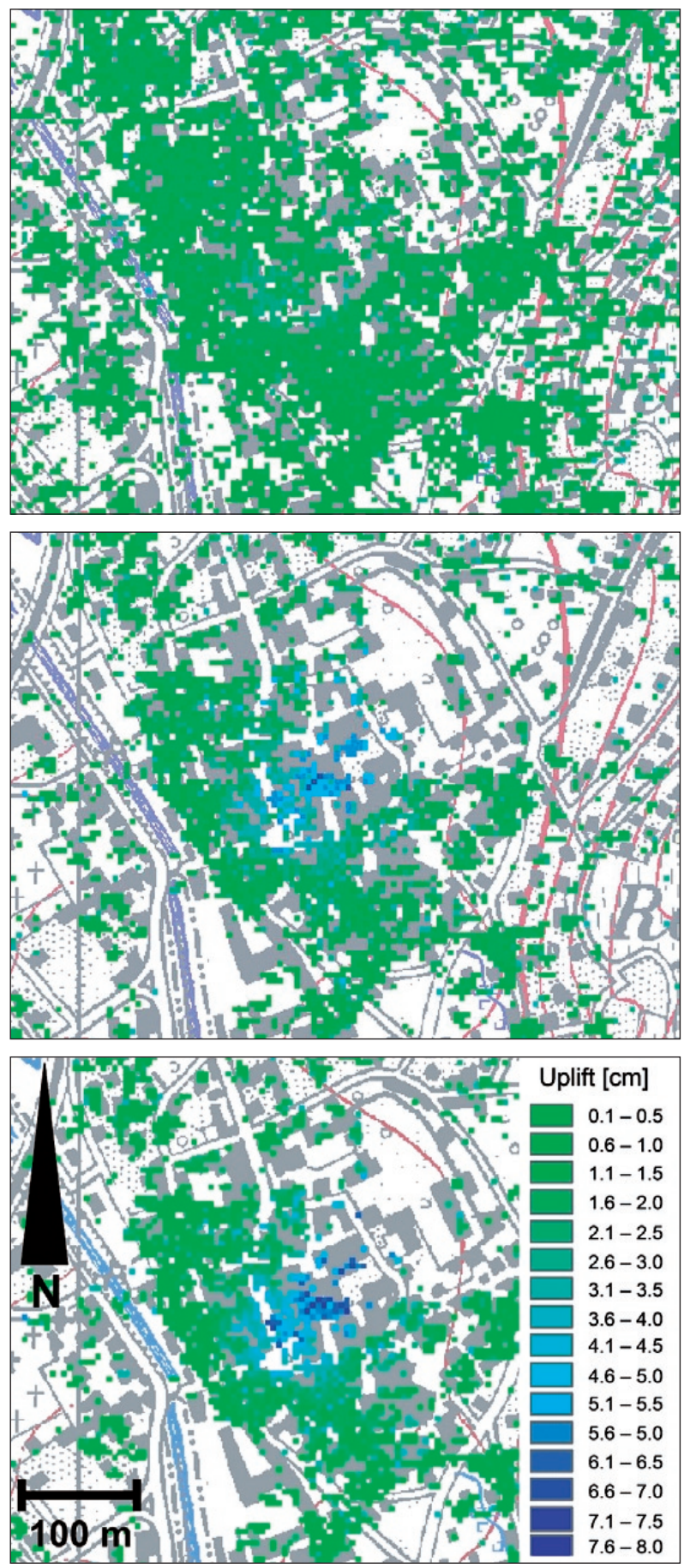

Fig. 15: Analysis of satellite-based ground level uplift monitoring by radar interferometry, a) July 2008 to 29. October 2008, b) July 2008 to 3. January 2009, c) July 2008 to 25. January 2009.

movement in the town centre of Staufen. An example of the chronological development of the ground movement, which was calculated by integrating individual interferograms is given in Fig. 15a-c. Missing areas in individual images are caused by a loss in coherence due to changes 


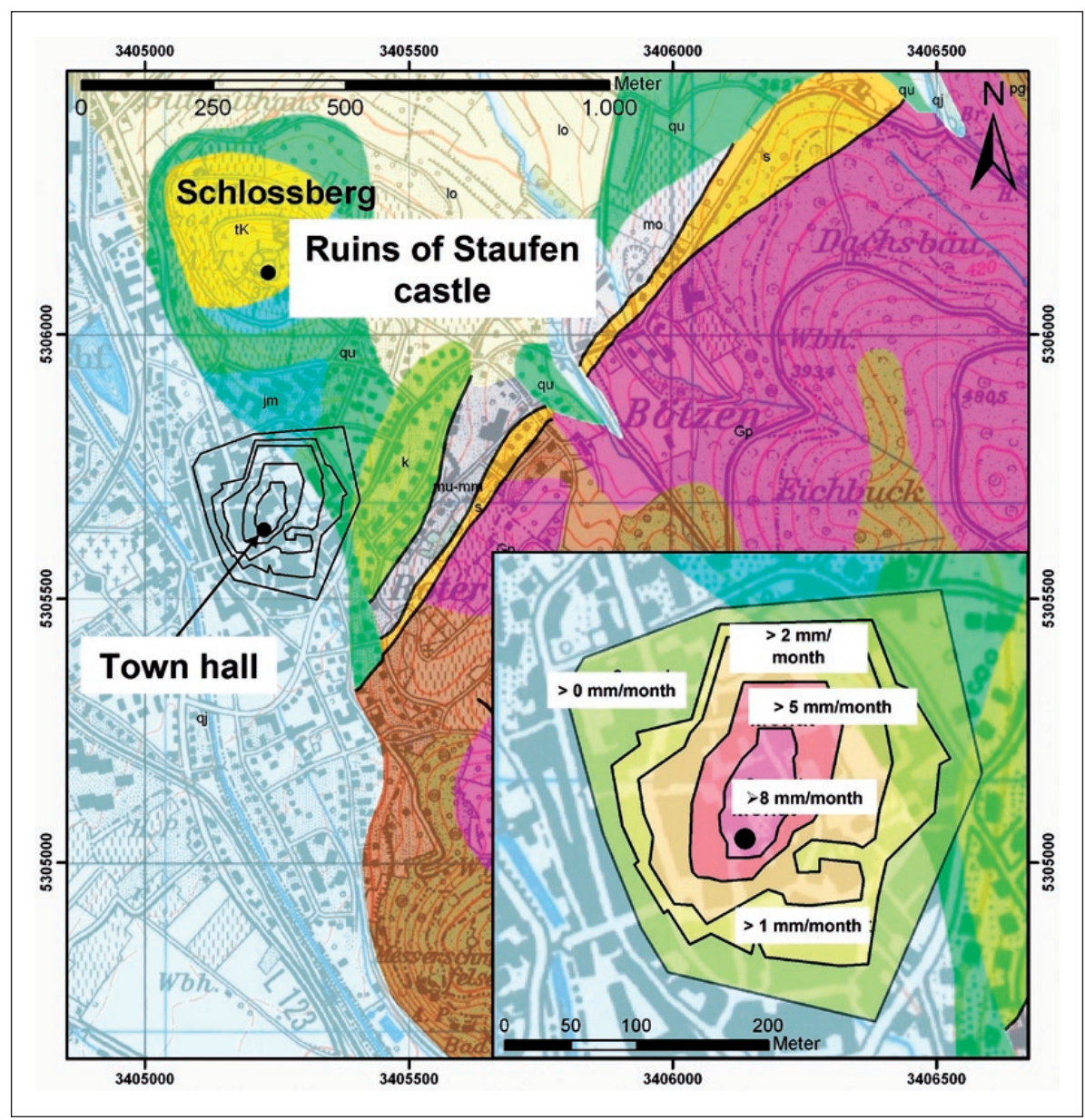

Fig. 16: Uplift rates in the city centre (LGRB 2009) plotted over the geological map Blatt 8112, Staufen im Breisgau, M 1:25.000.

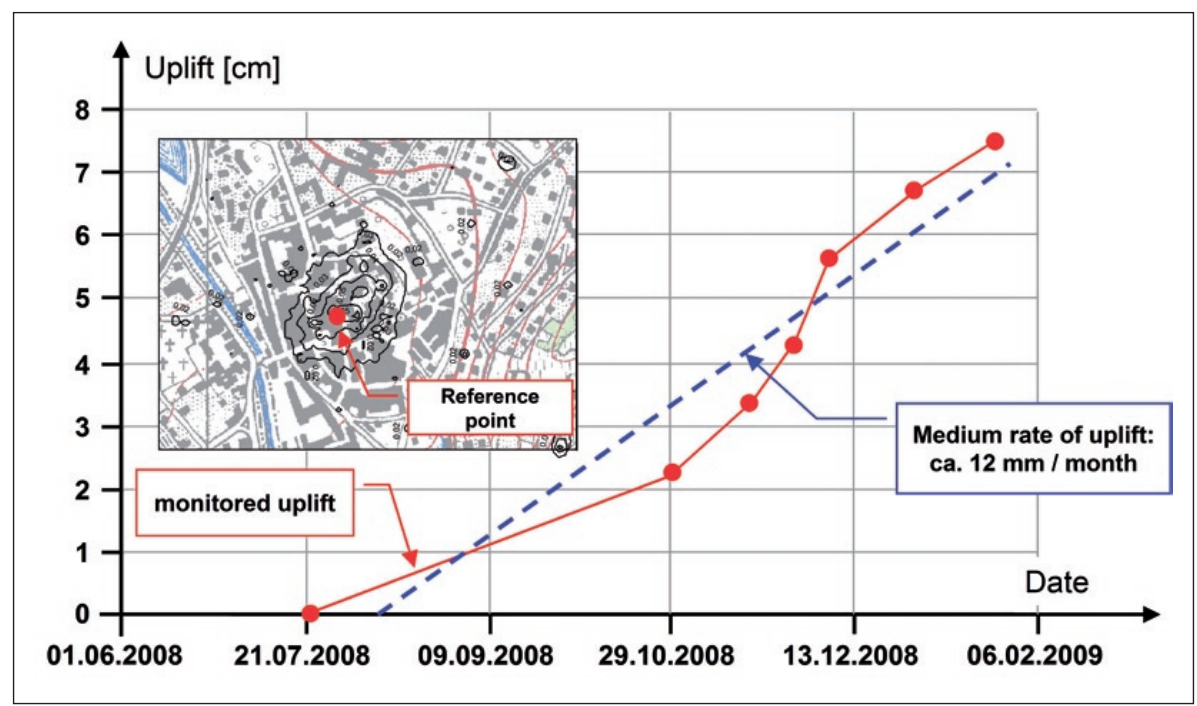

Fig. 17: Chronological development of the uplift of the town centre. in vegetation on the surface. Longer time ranges cause higher losses. The movement information was interpolated to achieve a better interpretation. Interpolations were used to calculate contour lines, which have been plotted over the available uplift results (Fig. 16). The timeuplift relationship for a selected location is plotted in Fig. 17. The calculated uplift rate is approx. $12 \mathrm{~mm}$ per month. This value correlates well with the geodetic leveling measurements (Schad 2008).

In general, results of the geodetic surveillance and satellite-based radar images (Fig. 15a-c) of the uplifted zone show an elliptical dome with a NNE-SSW axis (Fig. 16). This position coincides well with the bedding of the Jurassic, Keuper and Muschelkalk series. 


\section{MAPPING OF DAMAGES AND GEOLOGY}

Concepts for the technical restoration of the City of Staufen require detailed data on the complex geological situation. There are no outcrops in the damage area. Since the Grabfeld-Formation (Gipskeuper) is a subject to easy weathering, outcrops within this stratum are also not available. Structural geology data can only be achieved by analogue studies of the surrounding outcrops of younger or older beds with respect to the Middle and Upper Keu- per. Three very small outcrops of the Muschelkalk and the Tertiary could be investigated. Fig. 18 shows related jointing rose diagrams for the outcrop locations. The major directions can be mapped in the historic city centre of Staufen by categorizing the cracks on the outside walls of the buildings (Fig. 18).

Investigations into the intensity of damages to buildings were carried out. Four categories of damage were chosen:

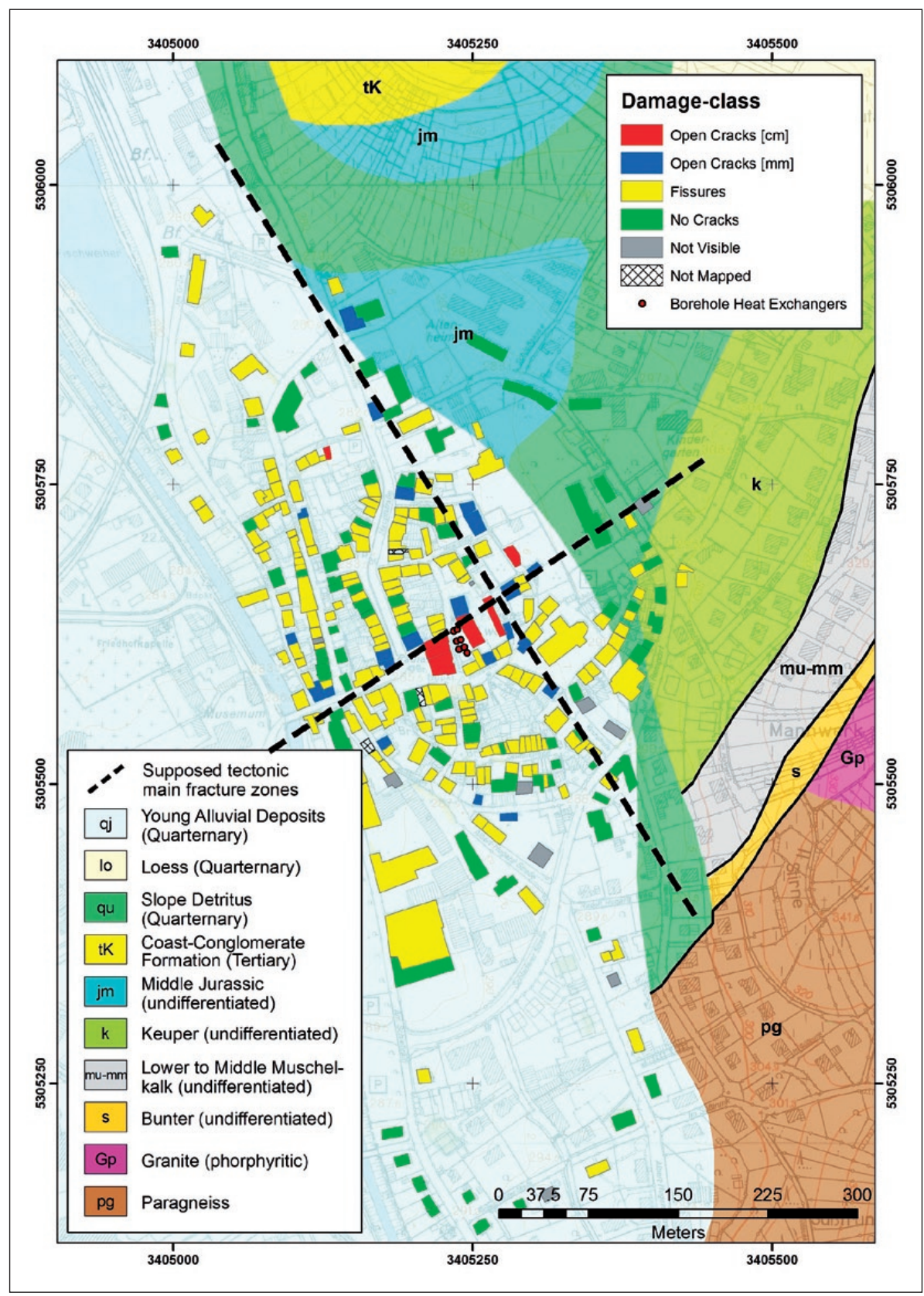

Fig. 18: Mapping of damages and geology.
- open fissures (width: centimeter),

- open fissures (width: millimeters),

- fissures smaller than one millimeter,

- no fissures.

Some buildings or parts of the buildings could not be evaluated. Most of the fissures were smaller than one millimeter. Some buildings have fissures of some millimeters width. More than four buildings have fissures of some centimeters width.

The zone of the most damaged buildings is consistent with the main orientation of geological fault structures, which is NNW-SSE and WSW-ENE (Fig. 18).

The orientation of building damages corresponds to the orientation of the discontinuities (Figs. 18 and 19) that were obtained by a field study in October 2009. It can be concluded that groundwater not only flows through drillings but now through discontinuities, too. The swelling process therefore cannot be stopped by sealing the BHE-Drillings. A larger area remediation approach must be found. 


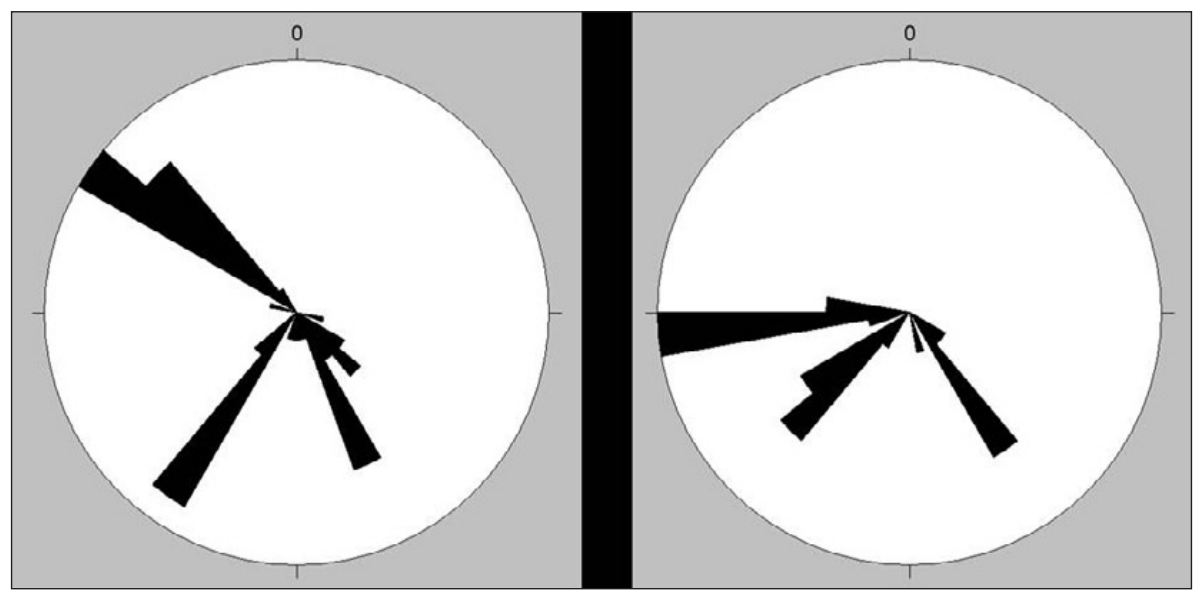

Fig. 19: Rose diagrams of outcrops.

Left: Upper Muschelkalk, Right:

Hauptrogenstein.

\section{CONCLUSIONS}

In total, four geological circumstances probably came into interaction due to an unsuitable drilling process, which resulted in the uplift caused by swelling: I) artesian groundwater in the karst section of the Gipskeuper, II) high anhydrite concentrations in that formation below, III) strong tectonization due to the position on the graben shoulder and IV) good connectivity to the Muschelkalk aquifer with a high hydraulic potential with respect to the Black Forest.

The uplift of the ground surface is obviously linked to large-scale swelling processes in the Gipskeuper. Furthermore, additional swelling of clay minerals (e.g., Corrensite) possibly occurs due to the contact with water. The contact with water has been rendered possible by hydraulic connections between the affected rocks and confined groundwater. These hydraulic connections were initiated by the geothermal drillings:

1. The chronological coherence between the drillings and the appearance of the cracks is a strong evidence for the causal coherence.

2. The contour lines of the uplift are elliptical around the well field (Figs. 15 and 16), which is an indication that the contact between water and Gipskeuper is located in the centre of the ellipse.

The natural causes discussed in Schad (2008), which explain the hydraulic pathways within and into the Gipskeuper strata by geological zones of weakness that opened up due to earthquakes, can be excluded, as damage symptoms and the damage history are not consistent with this hypothesis. Furthermore, there were no seismic events in the time period in question.

In 2007, only earthquakes with a magnitude up to 2.6 on the Richter scale were registered in the area
(LGBR 2007a, b). This magnitude is in no case able to produce such displacements.

The first step towards a complete tectonic and hydraulic investigation in and around the BHE field is done (LGRB 2010) but this is insufficient to supply a temporal and geometrical prognosis of the uplift. It is quite certain that the uplift will continue until the inflow of water into the swelling strata ceases, or until the entire hydraulically-accessible anhydrite has reacted to gypsum.

At this point, the rehabilitation concept of the geothermal well field has to fit in. Under supervision of the state geological survey (LGRB) the grouting of the BHE was begun in late 2009. A new method to perforate the BHE pipes from inside was applied to inject sealing grout into backfill failures (LGRB 2010). At the end of March 2010 about $14 \mathrm{~m}^{3}$ of grout were injected into the BHE field. The rate of uplift seemed to slow down in the centre of the swelling area. However, the number of damaged buildings still increases. This remedial measure was assisted by an ongoing groundwater withdrawal of about $2 \mathrm{l} / \mathrm{s}$ from the investigation well EKB 2, which leads to a drawdown of more than $100 \mathrm{~m}$.

Furthermore, gypsum is dissolving due to the continuous groundwater contact. This gives rise to recent karstification. Fine cavities will arise and will be distributed according to the distribution of the anhydrite and gypsum in the rock. These cavities will be closed due to the vertical stress of the overlying rocks, with subsidence of the ground surface as the consequence. If these fine distributed cavities get linked with each other, subsidence of the buildings into sinkholes may occur. A sinkhole event some tens of meters west of the town hall was reported 17 years ago. Therefore, this scenario is very 
likely. The recent decrease of the uplift rate could also be related to the beginning of karst formation or to the hydraulic drawdown. Further observations and investigations will be necessary to clarify this uncertainty.

The reconstruction of the City of Staufen is not expedient until the uplift ceases. In the short-term, only actions that serve the security and preserve the building substance and infrastructure should take place.

Sealing the geothermal wells currently seems to be the only option the stop the water inflow. This approach has to be carried out by the state geological survey. It is doubtful that this will affect the uplift in the entire 250 to $200 \mathrm{~m}$ elliptical dome.
In March 2009, a first boring to investigate the damage has been aborted, with the Lettenkeuper (Lower Keuper, Erfurt Formation) penetrated at only $16 \mathrm{~m}$ depth. In fact, it was expected at about 120 to $130 \mathrm{~m}$. A survey proved a tectonic fault in the geothermal well field. A second investigation boring was finished in February 2010. The current level of information suggests that BHE well S1 penetrated an artesian aquifer.

A first step to a geological model has been developed, but more information is now required.

\section{ACKNOWLEDGEMENT}

The authors gratefully thank Timothy D. Bechtel (Lancaster, PA, USA) for proofreading and language corrections. Furthermore we acknowledge the thoughtful comments of the editor Nico Goldscheider (Munich) and Annette E. Götz (Darmstadt) for critical comments.

\section{REFERENCES}

Chiesi, M., De Waele, J. \& P. Forti, 2010: Origin and evolution of a salty gypsum/anhydrite karst spring: the case of Poiano (Northern Apennines, Italy).Hydrogeology Journal, DOI 10.1007/s10040-0100576-2.

Gemeinde Staufen, 2007: Bohranzeige über Bohrarbeiten für die Errichtung einer erdgekoppelten Erdwärmepumpe auf dem Grundstück Flurstücks-Nr. 44.- Gemarkung Staufen, Gemeinde Staufen, Landratsamt Breisgau-Hochschwarzwald, Fa. Systherma, 28.03.2007.

Geyer, O. F. \& M. P. Gwinner, 1991: Geologie von BadenWürttemberg.- Schweizerbart, pp. 482, Stuttgart.

Goldscheider, N. \& T. Bechtel, 2009: Editors' message: The housing crisis from underground - damage to a historic town by geothermal drillings through anhydrite, Staufen, Germany.- Hydrogeology Journal, 17, 3, 491-493.

Landesvermessungsamt Baden-Württemberg, 1999: Geologische Karte von Baden-Württemberg, Blatt 8112: Staufen im Breisgau, $M$ 1:25.000.- Freiburg im Breisgau.
Landesvermessungsamt Baden-Württemberg, 1996: Geologische Karte von Baden-Württemberg: Freiburg im Breisgau und Umgebung mit Erläuterungen, $M$ 1:50.000.- Freiburg im Breisgau.

Landesanstalt für Umweltschutz Baden-Württemberg, 2005: Geotope im Regierungsbezirk Freiburg, 1. ed..Landesanstalt für Umwelt, Messungen und Naturschutz Baden-Württemberg, Karlsruhe.

LandratsamtBreisgau-Hochschwarzwald, 2007: Wasserrechtliche Erlaubnisfür den Einbau von zwölfErdsonden zum Betrieb einer Erdsonden-Wärmepumpenanlage auf Flst.-Nr. 44 der Gemarkung Staufen.- Landratsamt Breisgau-Hochschwarzwald, Freiburg.

LGRB Landesamt für Geologie, Bergbau und Rohstoffe Baden-Württemberg, 1977: Hydrogelogische Karte von Baden-Württemberg, Oberrheingebiet Bereich Kaiserstuhl - Markgräflerland.- Geologisch-Hydrologische Karte, Freiburg i. Br. Umweltministerium Baden-Württemberg, Stuttgart.

LGRB Landesamt für Geologie, Bergbau und Rohstoffe Baden-Württemberg, 2005: Leitfaden zur Nutzung von Erdwärme mit Erdwärmesonden.- Umweltministerium Baden-Württemberg, Stuttgart. 
LGRB Landesamt für Geologie, Bergbau und Rohstoffe Baden-Württemberg, 2007: Erdbebendienst: Epizentren von Erdbeben im Jahr 2007.- Umweltministerium Baden-Württemberg, Stuttgart.

LGRB Landesamt für Geologie, Bergbau und Rohstoffe Baden-Württemberg, 2007: Erdbebendienst: Seismisches Bulletin Baden-Württemberg.- Umweltministerium Baden-Württemberg, Stuttgart.

LGRB Landesamt für Geologie, Bergbau und Rohstoffe Baden-Württemberg (2009): Stadt Staufen TK 8112, Hebungsgeschwindigkeit, 05.10.2008 - 09.12.2008.Umweltministerium Baden-Württemberg, Stuttgart.

LGRB Landesamt für Geologie, Bergbau und Rohstoffe, Baden-Württemberg, 2010: Sachstandsbericht zur Erkundung und Sanierung des Schadensfalls Staufen, 22.02.2010.- Umweltministerium Baden-Württemberg, Stuttgart.

Petrat, L. \& A. Al-Enezi, 2006: Monitoring Oil Field Induced Subsidence using Satellite-Based Radarinterferometry.- In: GEO 2006 - $7^{\text {th }}$ Middle East Geoscience Conference in Manama, 27 $7^{\text {th }}-29^{\text {th }}$ March 2006, Bahrain.

Rauh, F., Spaun, G. \& K. Thuro, 2006: Assessment of swelling potential of anhydrite in tunnelling projects.- In: Culshaw, M. et al. (eds.) IAEG Engineering geology for tomorrow's cities, Proceedings $10^{\text {th }}$ IAEG International Congress, $6^{\text {th }}-10^{\text {th }}$ September 2006, Nottinham, England.

Rauh, F, 2009: Untersuchungen zum Quellverhalten von Anhydrit und Tongesteinen im Tunnelbau.Münchener Geowissenschaftliche Abhandlungen, Reihe B. Nr. 1, pp. 110, München.

Report, 2007a: Bohrprojekt Stadt Staufen mit 12 Bohrungen bis $140 \mathrm{~m}$ Tiefe/Länge, Gemeinde Staufen im Breisgau, Gemarkung Staufen, Flst.-Nr. 44.- Anzeigenbestätigung der Bohranzeige, eingereicht durch Stadt Staufen, 28.03.2007.
Report, 2007b: Fertigstellungsbericht Erdwärmesonden der Fa. Wälder Bau Bohrtechnik GmbH, Projekt Staufen i. Br. mit Lageplänen, Bohrprotokolle, Schichtenverzeichnissen, Verpressprotokollen, Druckprüfungsprotokollen.- Fa. Wälder Bau Bohrtechnik $\mathrm{GmbH}$, Schwarzenberg

Sass, I., Burbaum, U. \& L. Petrat, 2009: Staufen im Breisgau: Artesisches Grundwasser, Anhydrit und Karst im Konflikt mit geothermischen Bohrungen.- In: Schwerter, R. (ed.) 17. Tagung für Ingenieurgeologie und Forum Junge Ingenieurgeologen, $6^{\text {th }}-9^{\text {th }}$ May 2009, FDGG, 49, Zittau.

Schad, H., 2008: Sachverständigengutachten der Materialprüfungsanstalt der Universität Stuttgart.- Fachbereich/Abteilung Geotechnik vom 19.09.2008.

Schreiner, A., 1991: Geologie und Landschaft.- In: Hoppe, A. \& Hrsgb. Das Markgräflerland (eds.) Entwicklung und Nutzen einer Landschaft.- Ber. natforsch. Ges. Freiburg 81, 11-24, Freiburg, 1991, cited in Landesanstalt für Umweltschutz Baden-Württemberg, 2005: Geotope im Regierungsbezirk Freiburg, 1. ed.

Steiner, W., 1989: Wisenbergtunnel.- Sonderdruck aus Tagungsbericht D037 der Fachgruppe für Untertagbau des SIA, 69-80.

Steiner, W., 1993: Swelling Rock in Tunnels: Rock Characterization, Effect of Horizontal Stresses and Construction Procedures.- International Journal of Rock Mechanics and Mining Sciences \& Geomechanics Abstracts, 30, 4, 361-380.

Steiner, W., 2007: Einfluss der Horizontalspannungen auf das Quellverhalten von Gipskeuper.- Felsbau, $25,1,15-22$.

Wagenplast, P., 2005: Ingenieurgelogische Gefahren in Baden-Württemberg.- Information des LGRB, pp. 79. 46, Freiburg i. Br. 